\title{
Informovanost' žiakov základných škôl o globálnom polohovom systéme a hre geocaching vo vybraných mestách a obciach východného Slovenska
}

\section{Awareness of primary school pupils about global positioning system and navigating game geocaching in chosen towns and communities of east Slovakia}

\author{
Štefan Adamčák, Miroslav Nemec \\ Filozofická fakulta Univerzity Mateja Bela, Banská Bystrica, Slovensko
}

\begin{abstract}
Abstrakt
V našom príspevku sa zaoberáme informovanostou žiakov a žiačok o globálnom polohovom systéme a navigačnej hre geocaching. Prieskum sme realizovali vo vybraných mestách a obciach východného Slovenska na vzorke 437 žiakoch 8. a 9. ročníkov. Naše výsledky poukazujú na skutočnost', že skratku GPS jednoznačne pozná viac ako $63 \%$ respondentov (chlapci aj dievčatá) a dominantne GPS prijímač využívajú pri navigácii v meste, v prírode a pri navigácii v aute. Pojem geocaching nie je známy pre viac ako 60 \% žiakov. Záujem vyskúšat'si navigačnú hru geocaching na hodinách telesnej a športovej výchovy má viac ako 1/3 žiakov a žiačok. Rozdielnosti v názoroch respondentov (chlapci a dievčatá) boli iba $v$ troch prípadoch štatisticky signifikatne významné $(p<0,05)$.
\end{abstract}

\begin{abstract}
In our contrinbution we are dealing with awareness of boys and girls about global positioning system and navigating game geocaching. The research was realized in chosen towns and communities of East Slovakia on the sample of 437 pupils from 8th and 9th grade. Our results are pointing to the fact, that abbreviation GPS is clearly known by more than $62 \%$ respondents (boys and girls) and GPS receiver is used by them mainly in navigation in town, nature and when navigating in the car. Geocaching concept is not known for $60 \%$ respondents and the interest in trying the navigating game geocaching during the classes of Physical Education and Sport Education has got more than $1 / 3$ of respondents. Divergent opinions of respondents (boys and girls) were just three cases statistically significant $(p<0,05)$.
\end{abstract}

\section{Klúčové slová}

Geocaching, globálny polohový systém, žiaci a žiačky základných škôl.

\section{Key words}

Geocaching, Global Positioning System, primary school pupils (boys and girls).

Príspevok vychádzá z grantovej úlohy KEGA 002UMB-4/2014 „,Inovácia pohybových aktivit žiakov základných škôl realizovaných v prírodnom prostredi prostredníctvom hravých aktivít s využitím globálneho polohového systému“.

\section{ÚVOD}

Informačno-komunikačné technológie sprevádzajú naše každodenné životy, bez zretel'a na náš záujem, či vôl'u. Stali sa súčast'ou nášho každodenného života. Vytvárajú svet okolo nás, nakol'ko predstavujú významný prostriedok na prijímanie, odovzdávanie, vyhl'adávanie, triedenie a uchovávanie informácií akéhokol'vek druhu. Najväčšiu participáciu na týchto zmenách má podl'a HorákovejStejskalovej-Škapovej (2008) hlavne hromadné rozšírenie internetu, ktorý mimo iného priniesol aj demokraciu $\mathrm{v}$ prístupe $\mathrm{k}$ informáciám. 
Ďalším fenoménom súčasnej doby sú mobilné telefóny v podobe smartfónov. Serrano-HernantesGallardo (2013) uvádzajú, že smartfóny sa stali základným prenosným príručným prostriedkom komunikácie pre viac ako miliardu l'udí. Rôzne prístupy pri rozvoji mobilných aplikácií - iOS, Android alebo Windows, výrazne pomáhajú k mobilnej softwarovej evolúcií. Podl’a Gregovej (2012), Bartíka (2009) si žiak do školského prostredia prináša množstvo podnetov, skúseností, ale aj očakávaní, že aj tu bude pri svojej práci podobné technológie využívat'. Jedným z možných spôsobov vzdelávania žiakov je aj výučba s využitím ich vlastných mobilných telefónov, ktoré ponúkajú množstvo spôsobov ako zaujat', obohatit' každého žiaka. Z pohl'adu školskej telesnej a športovej výchovy to môže byt' napríklad navigačná hra geocaching a jej obmeny, ktoré ho môžu pozitívne motivovat' k pohybu a tým aj k samotnému predmetu, pretože uvedená hra v sebe spája prvky hrania sa a moderné technológie súčasnosti.

Vzhl'adom k uvedenému sme si stanovili ako ciel' nášho príspevku zistit' informovanost' žiakov a žiačok základných škôl o globálnom polohovom systéme a navigačnej hre geocaching.

\section{METODIKA}

V našom prieskume bola nosnou metódou anketa, ktorú sme vytvorili na základe potrieb grantovej úlohy. Odpoved’ový formulár ankety bol vytvorený a spracovaný v programe TAP 3 firmy Gamo Banská Bystrica. Pri vypĺňaní ankety bola žiakom poskytnutá primeraná inštruktáž. Prieskumný súbor pozostával zo 437 žiakov a žiačok 8. a 9. ročníkov z vybraných miest a obcí východného Slovenska (obr.1). Odpovede respondentov sme analyzovali z pohladu intersexuálnych rozdielov - chlapci, dievčatá.

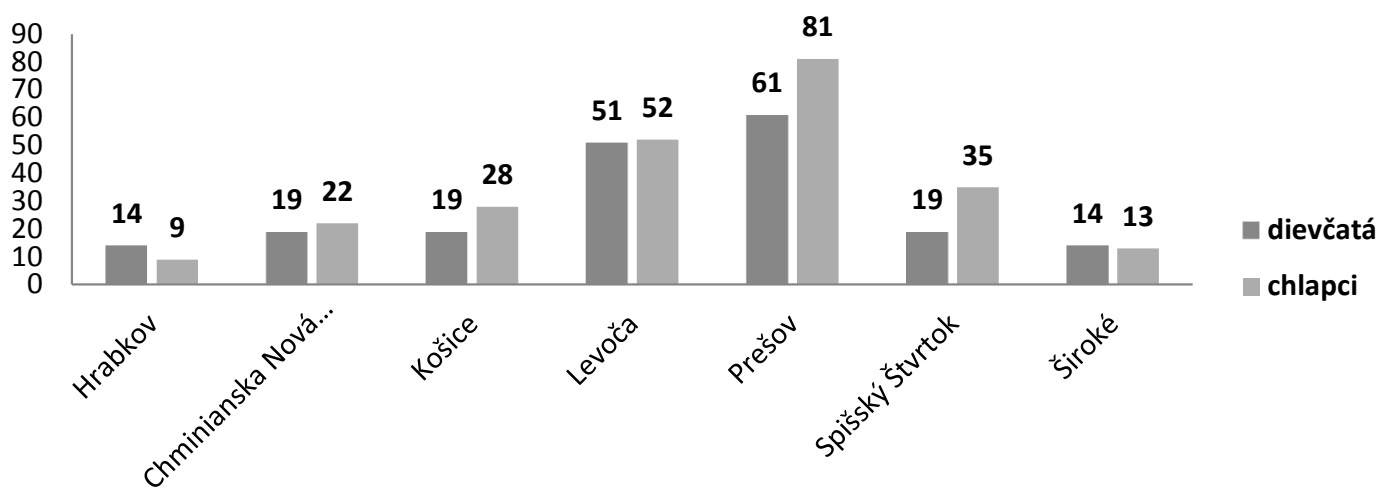

Obrázok 1 Charakteristika prieskumného súboru $(n=437)$

\section{Výsledky}

V úvode sme chceli zistit' základnú vec a to, či žiaci majú prístup na internet, pretože ten je nevyhnutnou podmienkou pre hru geocaching a to na akom mieste sa najčastejšie na internet pripájajú. Zistili sme (obr. 2), že prístup na internet nemá len 12,18 \% dievčat a iba $6,25 \%$ chlapcov. Vo vlastnom mobilnom zariadení má internet až 50,83 \% chlapcov a 41,62 \% dievčat. Viac ako $40 \%$ žiakov sa internet pripája bud' doma, v škole alebo vo verejných hot spotoch. Naše výsledky sú blízke Medzinárodnej štúdii počítačovej a informačnej gramotnosti ICILS, ktorá na vzorke 2994 žiakov Slovenska v roku 2013 zistila, že takmer všetci testovaní žiaci majú doma prístup na internet a viac ako polovica z nich priznáva doma viac než tri počítače (http://skolskyservis.teraz.sk/skolstvo). Z pohl'adu štatistického sú názory chlapcov a dievčat signifikantne rozdielne $(\mathrm{p}<0,05, \mathrm{p}=0,038)$. 
$75,00 \%$

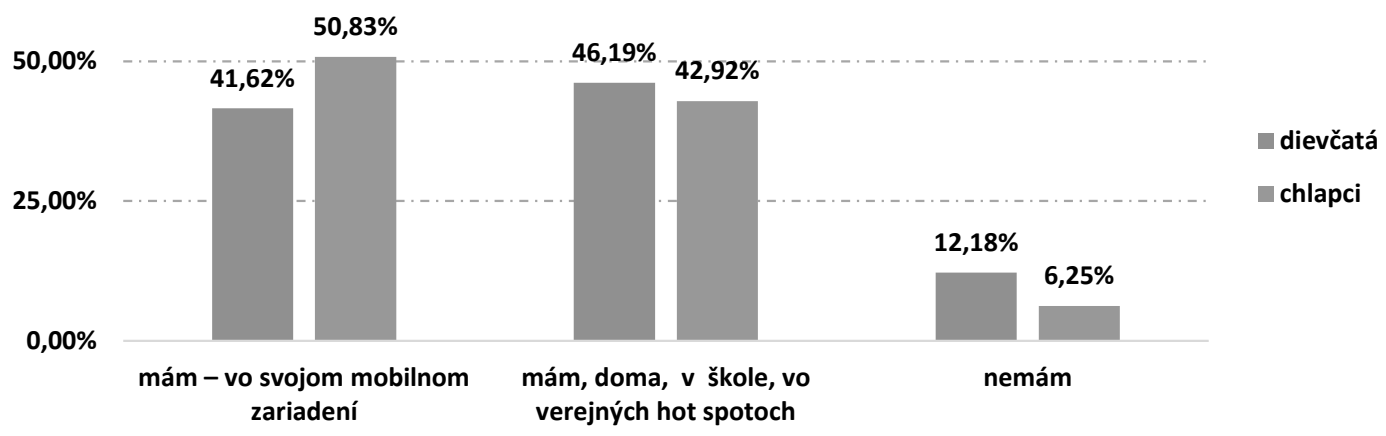

Obrázok 2 Možnosti prístupu k internetovému pripojeniu

Ako uvádza Vadaš (2003), výpočtová technika ovplyvňuje všetky činnosti žiakov nielen v škole, štúdiu, samoštúdiu ale aj pri využívaní vol'ného času a aj z tohto dôvodu sme chceli zistit', či žiaci vlastnia mobilný telefón a zároveň o aký druh telefónu ide. Zistili sme (obr. 3), že iba 13,71 \% dievčat a $6,25 \%$ chlapcov mobilný telefón nevlastní. Viac ako 70 \% žiakov (chlapcov aj dievčat) vlastní telefón v podobe smartfónu a 15,74 \% dievčat a 16,25 \% chlapcov vlastní klasický - tlačidlový mobilný telefón. Názory chlapcov a dievčat sú z pohl’adu štatistického signifikantne rozdielne $(\mathrm{p}<0,05, \mathrm{p}=0,030)$.

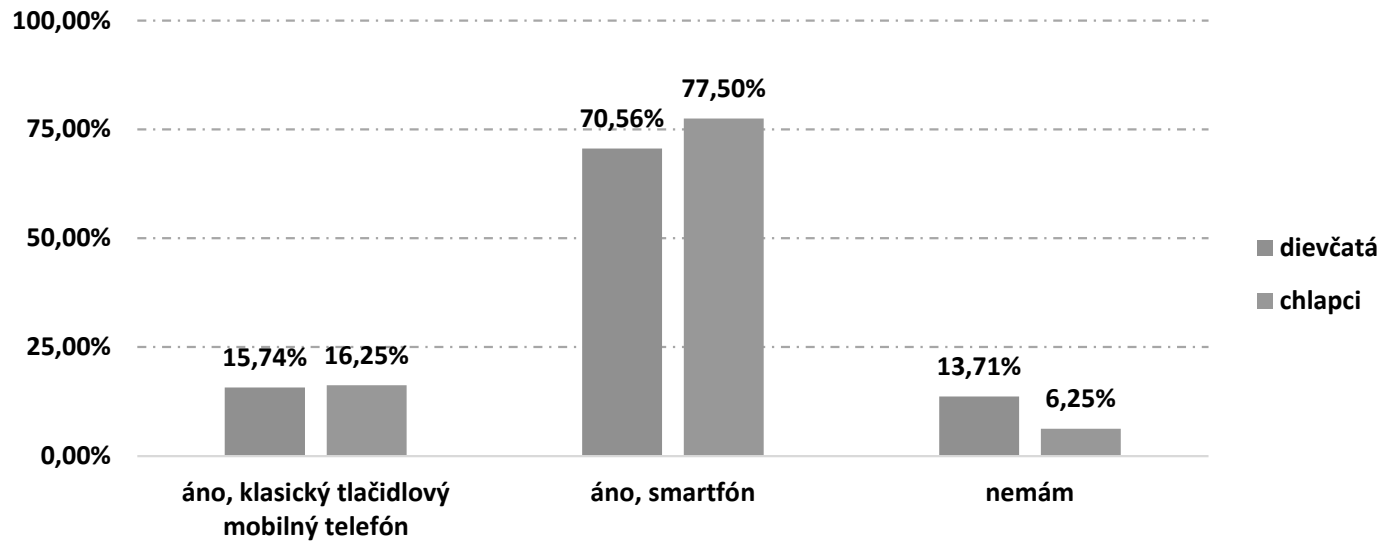

Obrázok 3 Druh vlastneného mobilného telefónu

Podl'a štatistiky, ktorú zverejnila TASR (http://www.teraz.sk/ekonomika/sr-mobily-trh-smartfon/105099-clanok.html) na Slovensku v roku 2014 dominovali smartfóny s dotykovou obrazovkou, ktoré používalo až $63 \%$ respondentov, zvyšok patril klasickým telefónom s hardvérovou klávesnicou (37\%). Je nutné však podotknút', že v roku 2011 bol tento pomer opačný - smartfóny vlastnilo len $30 \%$ a tzv. feature phones (klávesnicové telefóny) až $70 \%$ populácie. 


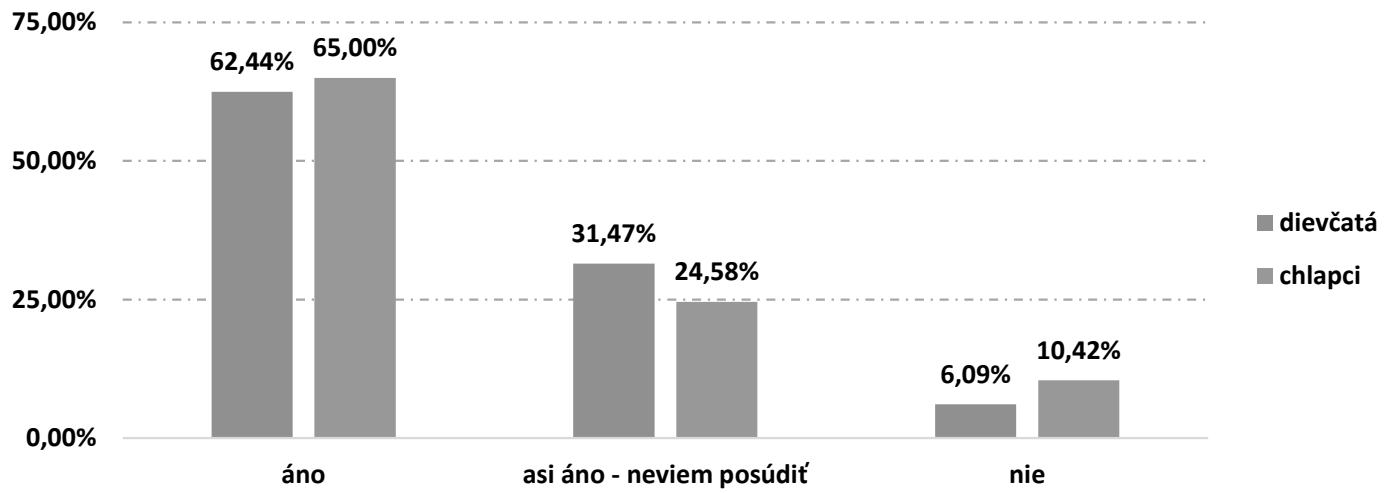

Obrázok 4 Poznanie skratky GPS

Z pohl'adu samotného navigačného systému (GPS) sme sa zamerali na zistenie, či respondenti poznajú jeho skratku = GPS (obr. 4). Viac ako 60 \% žiakov skratku pozná, čo zodpovedá aj skutočnosti, že vel'ká väčšina vlastní smartfón, kde v súčasnosti už GPS modul býva samozrejmost'ou. Uvedenú skutočnost' potvrdzuje aj fakt, že cena kúpeného telefónu bola v roku $2014 \mathrm{v}$ priemere 282 eur, pričom 32 \% Slovákov vlastní telefón nie starší ako 1 až 2 roky a až 23 \% vlastní telefón nie starší ako 1 rok (http://www.teraz.sk/ekonomika). Prekvapilo nás, že skratku jednoznačne nepozná $6,09 \%$ dievčat a 10,42 \% chlapcov. Rozdiely v názoroch chlapcov a dievčat sú z pohl'adu štatistického nevýznamné $(\mathrm{p}=0,113)$.

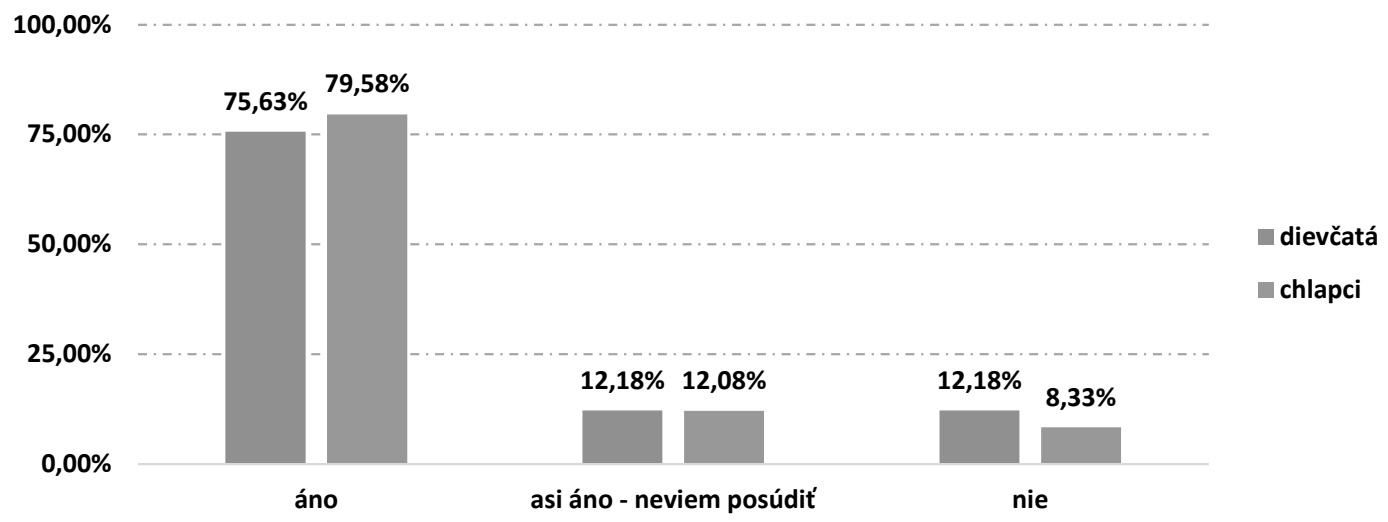

Obrázok 5 Praktické skúsenosti s GPS prijímačom

V d'alšej otázke sme chceli prakticky potvrdit' odpovede z predchádzajúcej otázky a pýtali sme sa, či majú respondenti aj nejaké praktické skúsenosti s GPS prijímačmi (obr. 5). Takmer 80 \% žiakov $(75,63 \%$ dievčat a 79,58 \% chlapcov) uviedlo, že má praktické skúsenosti s GPS prijímačom. Odpoved” „nie“, ktorú uviedlo 12,18 \% dievčat a $8,33 \%$ chlapcov, nám potvrdila, že podobne ako pri vlastníctve prijímača s GPS, aj pri jeho praktickom používaní je záporný vzt’ah len nízke percento. Podobne sa odvíjali aj odpovede na to aké možnosti majú pri prístupe k užívatel'skému prijímaču GPS (obr. 6). Prakticky 57 \% dievčat a $64 \%$ chlapcov má prístup k GPS prostredníctvom smartfónu, resp. vlastní užívatel'ský GPS prijímač. Z pohl'adu prístupu ku prijímaču s GPS sa percentá záporných odpovedí výraznejšie nenavýšili. Nevlastní a ani si ho nemajú možnost' požičat' až 8,63 \% dievčat a 11,67 \% chlapcov. Aj tu sú rozdiely v názoroch chlapcov a dievčat z pohl'adu štatistického nevýznamné $(\mathrm{p}=0,051)$. 


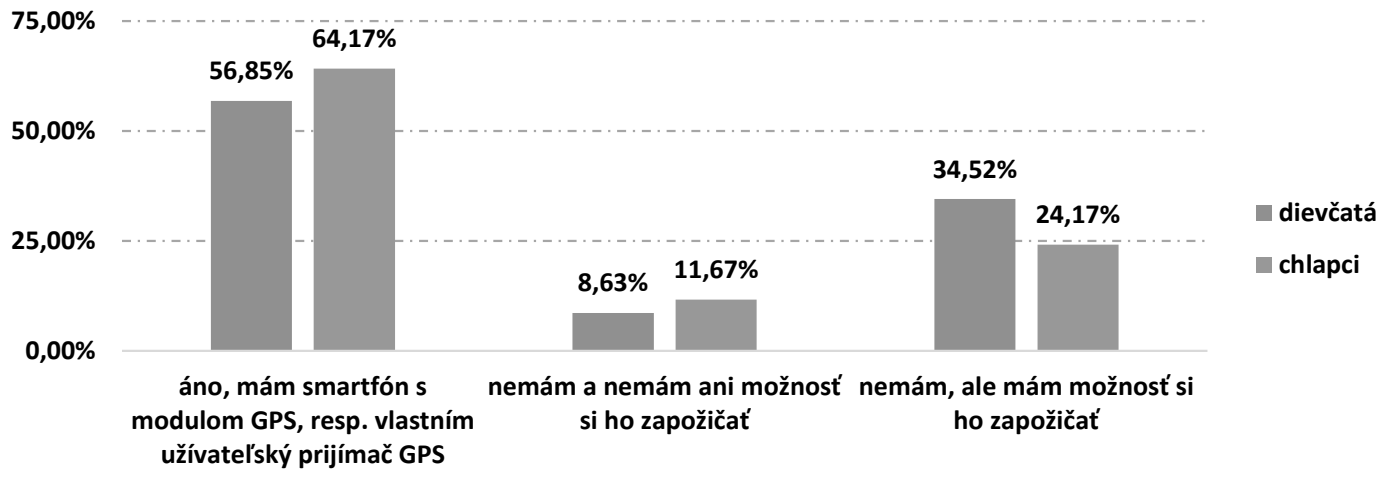

Obrázok 6 Prístup k užívatel'skému prijímaču GPS

Následne sme chceli vediet', pri akých činnostiach najčastejšie užívatel'ský prijímač GPS respondenti využívajú, Vnímali sme pritom skutočnost', že uvedený systém sa objavuje prakticky v množstve aktivít nášho každodenného života - napríklad autonavigácia, geodézia, bezpečnostné služby, pol'nohospodárstvo, lov zveri, šport a i.

$75,00 \%$

$50,00 \%$

$47,92 \%$

$46,70 \%$
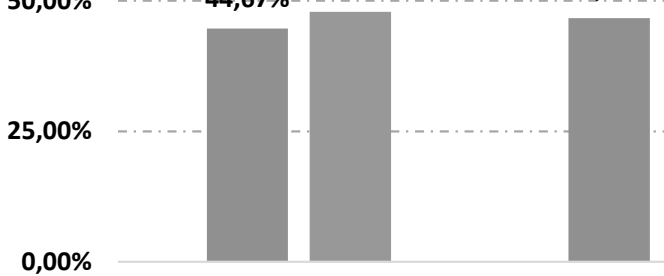

$42,92 \%$

na orientáciu (v meste, $v$

nepoužívam

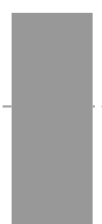

dievčatá prírode, $v$ aute a pod.)

Obrázok 7 Činnosti, pri ktorých je najčastejšie využívaný prijímač GPS

Zistili sme (obr. 7), že v podstate podobne je GPS využívané na všeobecné činnosti $(44,67 \%$ dievčat a 47,92 \% chlapcov) ako aj je vôbec nepoužívané (46,70 \% dievčat a 42,92 \% chlapcov). Len $8,63 \%$ dievčat a $9,17 \%$ chlapcov uviedlo, že GPS použiva pri navigačných hrách. Rozdiely v názoroch chlapcov a dievčat sú z pohl'adu štatistického nevýznamné $(p=0,730)$.

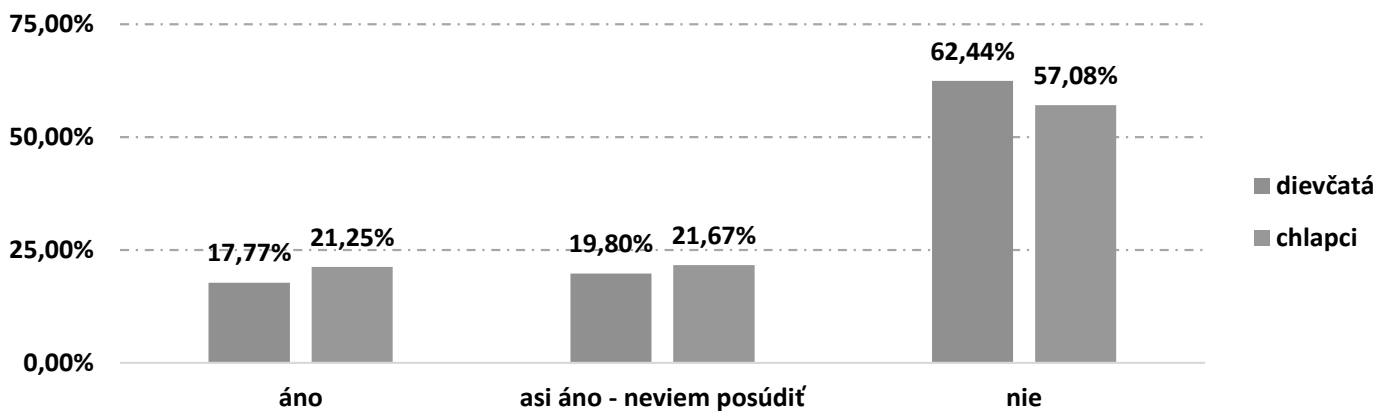

Obrázok 8 Informovanost’ o pojme geocaching 
Z pohl'adu nášho prieskumu jednou z najdôležitejších oblastí bola informovanost' o poznaní geocachingu. Zistili sme (obr. 8), že pojem geocaching pozná $17,77 \%$ dievčat a $21,25 \%$ chlapcov. Záporný výsledok (termín geocaching nepoznám) sa objavil pre nás u vel'mi vysokého percenta respondentov (skoro $60 \%$ ). Práve to je dôvod prečo by bolo podl’a nás vhodné oboznámit’ žiakov a žiačky nielen s pojmom ale aj samotným obsahom navigačných hier, ktoré môžu prispiet' $\mathrm{k}$ zatraktívneniu edukačného procesu. Rozdiely v názoroch chlapcov a dievčat sú z pohl’adu štatistického nevýznamné $(\mathrm{p}=0,504)$. To, že respondenti nepoznajú pojem sa prejavilo aj pri odpovediach na otázku o poznaní obsahu hry geocaching. Výsledky (obr. 9) boli blízke vyhodnoteniu predchádzajúcej otázky. Aj z pohl'adu štatistického boli rozdiely názorov chlapcov a dievčat rovnako nevýznamné $(\mathrm{p}=0,235)$. Jednou z možností ako tento stav zmenit' je aj vytváranie schránok (skrýš) priamo pri alebo v školách. Príkladom sú školy ako ZŠ Krosnianska 4, Košice, ZŠ Bukovecká 1, Košice (www. geocaching.com), kde spoluzakladatel'mi sú aj samotní žiaci škôl. Ďalšou možnost'ou je aj verejná popularizácia geocachingu, podobne ako sa to deje od roku 2012 v Nitre, kde sa každoročne pre širokú verejnost' organizuje podujatie „Nitracaching“, ktoré je zamerané na spoznávanie prírodných a historických pozoruhodností v meste a jeho okolí práve prostredníctvom geocachingu (http://skolskyservis.teraz.sk/volny-cas).

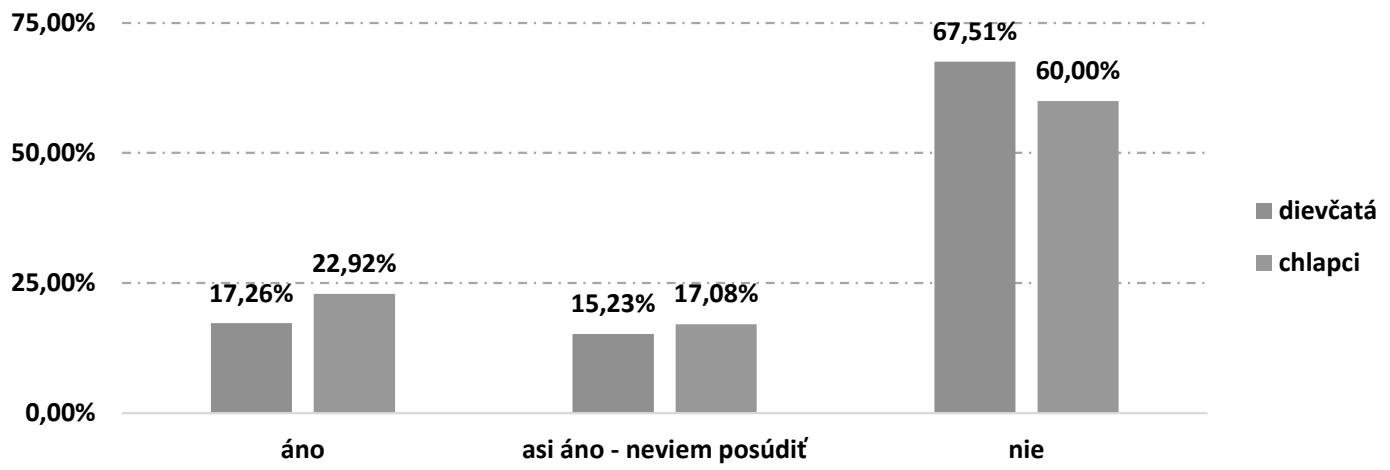

Obrázok 9 Poznatky o navigačnej hre geocaching

V d’alšej časti ankety sme sa rozhodli zistit', či respondenti poznajú nejaké aplikácie súvisiace s hrou geocaching. Viac ako $15 \%$ dievčat a $23 \%$ chlapcov aplikácie pozná (obr. 10). Toto zistenie potvrdzuje, že súčasná mládež vo vel'kej miere využiva telefóny na surfovanie po internete a tak má možnost' zoznámit' sa s množstvom aplikácii, medzi ktoré patria aj navigačné hry. Ked’že väčšina z nich sú neplatené je aj prístup k ním l'ahší. Názory chlapcov a dievčat sú z pohl'adu štatistického vysoko signifikatne rozdielne $(\mathrm{p}<0,01, \mathrm{p}=0,009)$.

$75,00 \%$

$55,33 \%$

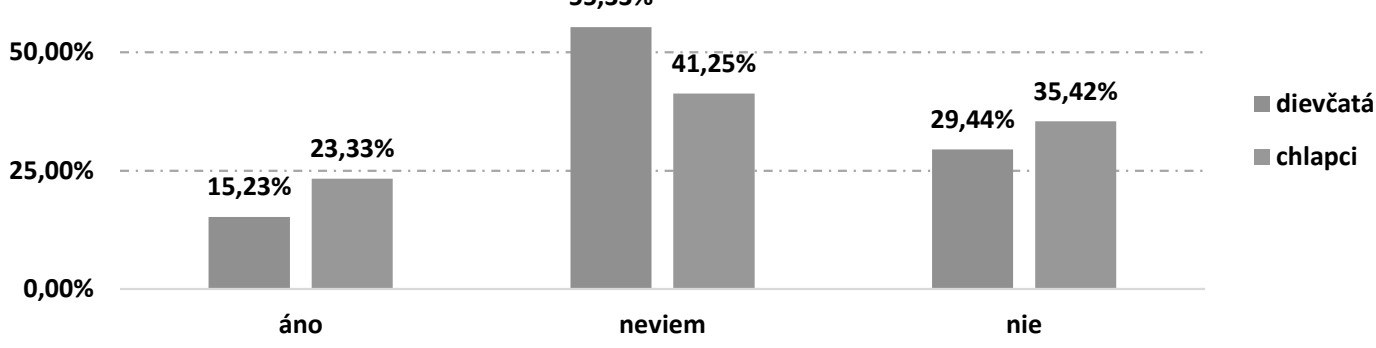

Obrázok 10 Poznatky žiakov a aplikáciách pre hru geocaching 
Z vyhodnotení ankety d’alej vyplýva (obr. 11), že hráčov geocachingu pozná iba 18,78 \% dievčat a $16,67 \%$ chlapcov, pričom viac ako $63 \%$ dievčat a chlapcov nepozná vo svojom okolí nikoho kto by hru geocaching realizoval. Rozdiely v názoroch chlapcov a dievčat sú z pohl'adu štatistického nevýznamné $(\mathrm{p}=0,616)$.

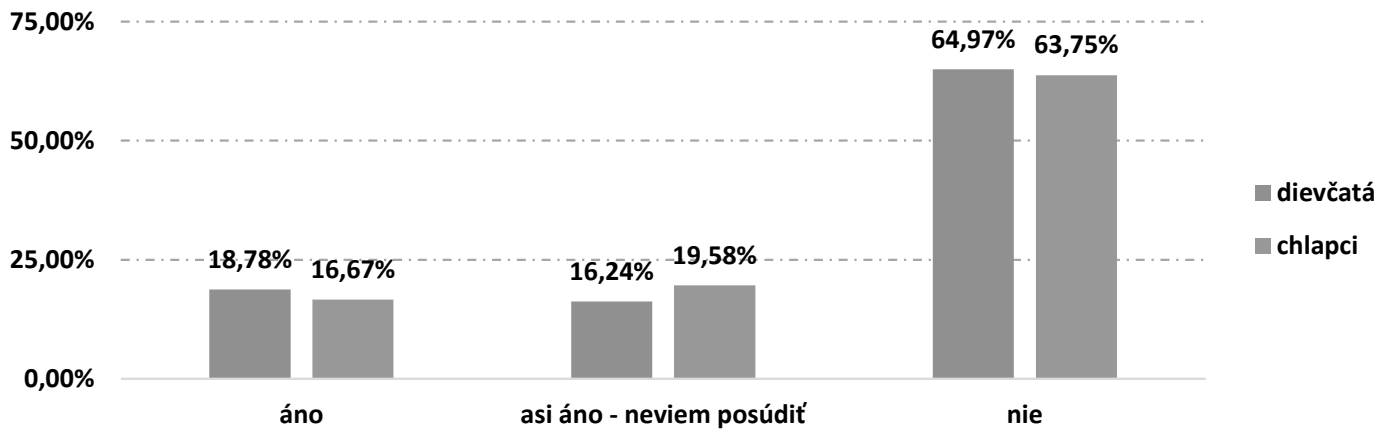

Obrázok 11 Informovanost' o aktívnych hráčoch geocachingu

Predposlednou otázkou ankety sme zist'ovali, či by si respondenti chceli hru geocaching vyskúšat' v rámci hodín telesnej a športovej výchovy, pretože ako uvádza Partová (2002) pre mnohých žiakov nie je motivujúce, ak sa v škole nepoužívajú prostriedky na úrovni súčasnej doby, moderné technológie nevynímajúc. Tri možnosti odpovedí mali v podstate vyrovnanú úroveň (obr. 12). Tak kladnú odpoved”,áno“, ako aj „nie“, resp. „,asi áno - neviem“ sme zaznamenali u viac ako tretiny dievčat a chlapcov, čo považujeme za pozitívne zistenie. Najmä z toho pohl'adu, že len niečo viac ako $10 \%$ našich respondentov uviedlo v predchádzajúcich odpovediach, že má nejaké informácie o tejto navigačnej hre resp. že ju ani nepozná. Rozdiely v názoroch chlapcov a dievčat sú z pohl’adu štatistického nevýznamné $(\mathrm{p}=0,656)$.

$50,00 \%$

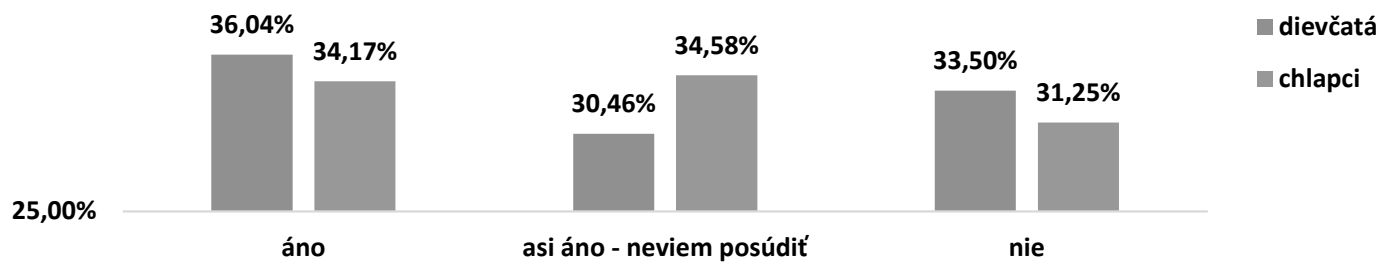

Obrázok 12 Záujem o zaradenie hry geocaching do hodín telesnej a športovej výchovy

Posledná otázka nám mala priniest' informáciu o tom, či sú respondenti ochotný sa venovat' geocachingu a navigačným hrám aj vo svojom vol'nom čase. Výsledok nám čiastočne sklamal, ale zároveň potvrdil skutočnost', že súčasná mládež len málo inklinuje k aktivitám, ktoré si vyžadujú pohyb, fyzické nasadenie a zvýšené myšlienkové úsilie (Bet’ák, 2014). Respondenti pri odpovedi na otázku, či by chceli navštevovat' záujmový krúžok, ktorý by sa venoval geocachingu neprejavili vel'ký záujem (obr. 13). Odpoved' áno uviedlo iba 8,12 \% dievčat a iba 12,50 \% chlapcov. Odpoved' jednoznačné „,nie“ uviedlo viac ako 56 \% žiakov. Ani pri vyhodnotení tejto otázky neboli rozdiely v názoroch chlapcov a dievčat $\mathrm{z}$ pohl'adu štatistického významné $(\mathrm{p}=0,161)$. 


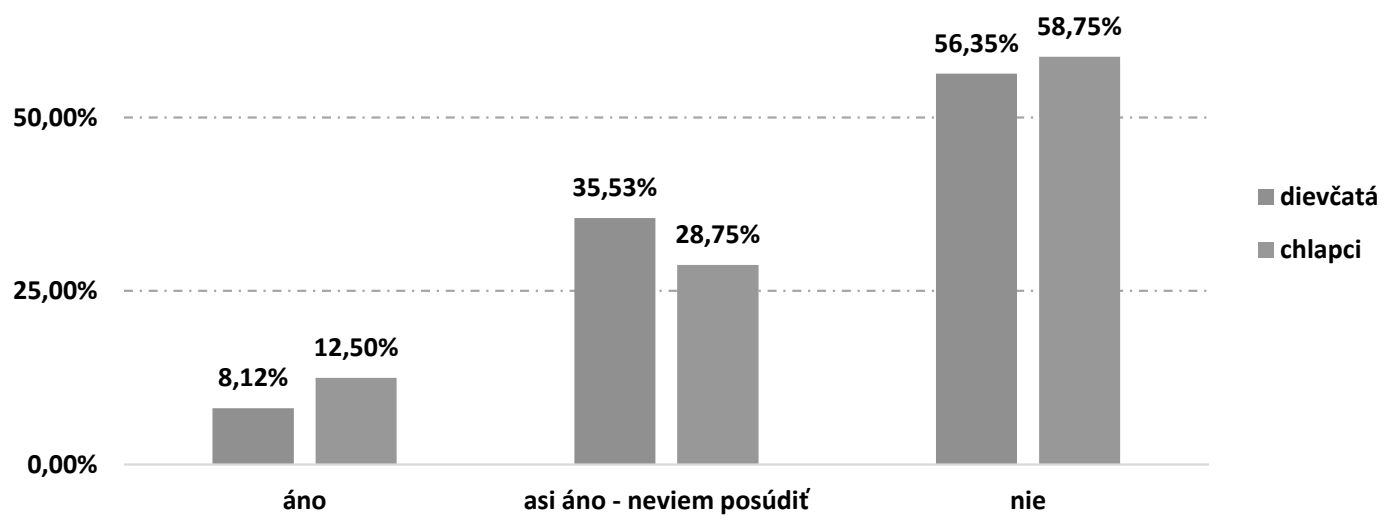

Obrázok 13 Záujem o navštevovanie krúžku so zameraním na geocaching

\section{Záver}

Vzhl'adom na rozsah našej vzorky respondentov a parciálnu čast' skúmanej problematiky nemôžeme plnohodnotne zovšeobecňovat' naše závery, je však možné poukázat' na viaceré aktuálne skutočnosti vyplývajúce z nášho prieskumu, ktoré vystihujú daný región Slovenska a zhrnieme ich do niekol'kých bodov:

$\checkmark$ žiaci a žiačky základných škôl disponujú vo viac ako $70 \%$ mobilným telefónom v podobe smartfónu, čo prevyšuje aj celoslovenský priemer;

$\checkmark$ skratku GPS v súčasnosti pozná viac ako $62 \%$ žiakov a žiačok;

$\checkmark$ samotný pojem geocaching nepozná takmer $60 \%$ žiakov a žiačok;

$\checkmark 1 / 3$ žiakov a žiačok prejavila záujem vyskúšat' si hru geocaching na hodine telesnej a športovej výchovy.

Sme presvedčení, že geocaching predstavuje modernú vol’no-časovú aktivitu, ktorá spája prvky športu, sút’aže a turistiky, určenú pre široké vrstvy verejnosti, prístupnú v tých najrozmanitejších podobách využitel'nú aj v školskej telovýchovnej praxi. Záleží však na učitel’och telesnej a športovej výchovy ako sa s modernými technológiami v praxi „popasujú“, ako túto hravú aktivitu žiakom a žiačkam bližšie sprostredkujú a v neposlednom rade, ako zatraktívnia samotný predmet tak, aby patril medzi najoblúbenejšie predmety vo vyučovaní aj v budúcnosti.

\section{Literatúra}

ADAMČÁK, Š., \& KOZAŇÁKOVÁ, A. (2011). Zábavné činnosti s GPS. In Zborník Telesná výchova a šport na školách. Ružomberok: Katolícka univerzita, 2011, s.4-11.

BARTÍK, P. (2009). Postoje žiakov základných škôl k telesnej výchove a športu a úroveň ich teoretických vedomostí z telesnej výchovy v intenciách vzdelávacieho štandardu. Banská Bystrica: FHV UMB, 2009, 132s.

BEŤÁK, B. (2014). Pohybové a športové aktivity vo vol’nom čase žiakov stredných škôl v Poprade. In Telesná výchova a šport $v$ živote človeka. Zvolen: Technická univerzita, 2014, s. 76-85.

GREGOVÁ, E. (2012). Využitie inovatívnych metód a informačno komunikačných technológii v prírodopise pri opakovaní učiva. Bratislava: Metodicko-pedagogické centrum, 2012, s. 29.

HORÁKOVÁ, I., STEJSKALOVÁ, D., \& ŠKAPOVÁ H. (2008). Strategie firemní komunikace. Praha: Management Press.

PARTOVÁ, E. (2002). Informačné komunikačné technológie vo vyučovaní elementárnej matematiky. In Pedagogické spektrum, roč. 11 , č. 3/4, 2002, s. 50-54. 
SERRANO, N., HERNANTES, J., \& GALLARDO, G. (2013). Mobile Web App (Sowtware technology). In Software - IEEE computer society, september/october 2013, s. 22-27.

VADAŠ, R. (2003). Informačné a komunikačné technológie a ich miesto na 1. stupni základnej školy. In Slovenský učitel'príloha Technológie vzdelávania. č. 1, 2003, s. 12-14. Nitra: Slovidac, 2003.

\section{Zoznam internetových odkazov}

http://skolskyservis.teraz.sk/skolstvo

http://www.teraz.sk/ekonomika

http://www.geocaching.com

http://www.teraz.sk/ekonomika/sr-mobily-trh-smartfon/105099-clanok.html

\section{Kontaktná adresa:}

Štefan Adamčák

Filozofická fakulta Univerzity Mateja Bela, Tajovského 40, 97401 Banská Bystrica, Slovakia stefan.adamcak@umb.sk 